\title{
THE INFLUENCE OF THE EDUCATIONAL LEVEL AND THE EMPLOY- MENT OF PARENTS ON THE DEVELOPMENT OF THE PHONOLOGICAL AWARENESS OF PUPILS OF THE LOWER PRIMARY SCHOOL AGE
}

Leila Begić, ${ }^{1, a}$

\author{
Original scientific paper
}

\begin{abstract}
Zamir Mrkonjića
Mirza Sitarevićc

Šejla Kunićc
\end{abstract}

${ }^{a}$ Faculty of Education and Rehabilitation, University of Tuzla, Bosnia and Herzegovina

'Public institution, Primary school „,Duboki potok“, Srebrenik, Bosnia and Herzegovina

"Public institution, Primary school „Han Bila“, Travnik, Bosnia and Herzegovina

Received: 2019/2/11

Accepted: 2019/3/22

\begin{abstract}
The main goal of this research was to examine the influence of the educational level and employment of parents on the development of phonological awareness of pupils of first and second primary school grades. The sample of respondents consisted of a total of 70 students whose age ranged from 78 months to 104 months. Observing respondents in relation to gender, 37 were male and 33 were female. The research was conducted in primary schools in the municipalities of Travnik and Novi Travnik in Bosnia and Herzegovina. The obtained results showed that the level of parents' education and the employment of parents influence the development of the phonological awareness of pupils of the first and second grades of primary schools. Namely, phonological awareness was more developed with pupils whose parents were employed and had a higher education level. The obtained results point to the need for professionals to pay more attention to the phonological development of children coming from families of low socioeconomic status. It is very important to timely identify students with difficulties in the development of phonological awareness with the aim of organizing and providing adequate professional assistance. If the student has difficulty in the field of phonological awareness, in that case the mentioned difficulties may also have a negative effect on the learning skills in other areas.
\end{abstract}

Keywords: phonological awareness, lower primary school age, parental education level, pupils, parents' employment

\section{INTRODUCTION}

Phonological awareness is a skill that involves the ability to perceive, manipulate, and reflect on language voices (Anthony \& Lonigan, 2004). Andrešić et al. (2010) determine the phonological awareness as the ability to dis- assemble words to voices and make voices in words, to connect voices with letters, and to understand the written word. For Yopp and Yopp (2000) phonological awareness is placed within a wider area called metalinguistic consciousness, which refers to the ability to think about language.

\footnotetext{
${ }^{1}$ Correspodence to:

Leila Begić, Faculty of Education and Rehabilitation, University of Tuzla, Bosnia and Herzegovina

Univerzitetska 1, 75000 Tuzla, Bosnia and Herzegovina

Phone:+38761502350

E-mail: leila.begic@untz.ba
} 
Metallinguistic awareness means being aware and having control over your own language, and it is the ability to direct attention to language, regardless of the content of the language itself.

Phonological awareness, coupled with proper spoken language development and the established link phonemism, are included in the reading and writing predecessor skills (Andrešić et al., 2010). Pre-reading skills are a prerequisite for the development of reading skills, and they develop in pre-school age (Andrešić et al., 2010; Leffel \& Suskind, 2013). Knowing the level of development of pre-reading skills at a certain age of a child's development can help us in early recognition of children who might have difficulties in later reading (Eric, 2014). Numerous authors have tried to determine how different circumstances can affect phonological awareness in children, and the socioeconomic status has emerged as one very important factor that can affect both phonological awareness and other developmental areas in the child. The quality of the family is defined through the socioeconomic status that constitutes the economic position of the family, the educational level of the father and mother, the furnishing of the home with stimulating and cultural content, or the organization and structure of the home life. Family socioeconomic status can have an impact on the child's development by primarily affecting the psychological functioning of the parents, and therefore the various aspects of upbringing, the environment in which the child grows up, and so on (ČudinaObradović, 1995). Leffel and Suskind (2013) state that the linguistic environment of the child at the earliest is crucial to his cognitive development, school readiness and ultimate achievement in school. At the beginning of schooling, children differ strongly in the degree of development of phonological awareness (Kobola, 1977). How much the children are sensitive to phonemes in speech is partially dependent on the language experiences they had in the past years, and partly on the genetic factor (Yopp \& Yopp, 2000). Child development and maturity of various developmental aspects, including cognition, motoring, social development, and speech - language development are important factors associated with starting school. Also, the learning of spoken and linguistic skills is essential for the educational achievement of students, and the success of acquiring school knowledge depends to a large extent on speech - language abilities (Begić, Duranović, \& Karagić, 2016). For this reason, it is recommended that the environment in which the children are staying are to a greater extent be filled with different reading material, and that they hear reading from the earliest days. This is the best way to encourage proper speech-language development in children (Smajlović, Begić, \& Karagić, 2017). The above can only be provided by families with higher socioeconomic status, i.e. highly educated financially independent parents. A number of children, and most often those children from linguistically rich homes where they listened to stories and who participated in numerous word games, start school with already developed phonological awareness. A large number of children develop sensitivity to voices in the first two years of schooling. In these cases, this happens without special effort, and only the exposure to the stimulating classroom environment and the reading learning program is sufficient. But for some children, this is not enough, but they need additional training with the aim of developing phonological awareness (Yopp, 1995). Academic skills, in correlation with a low-literacy family environment, adversely affect the child's future skills (Aikens \& Barbarin, 2008). This research sought to determine whether the socioeconomic status, that is, the education of mother and father, and their employment have an impact on the development of the phonological awareness of their children.

\section{METHODS}

\section{Sample respondents}

This study covered a total of 70 pupils of first and second grades of primary schools in the municipalities of Travnik and Novi Travnik in Bosnia and Herzegovina. 37 respondents were male and 33 were female. The chronological age of the subjects ranged between 78 and 104 months, respectively, 6 years and 6 months, and 8 years and 8 months.

\section{Sample variables}

The variables used in this research can be divided into two groups: socioeconomic status variables and variables for testing phonological awareness.

\section{Variables of socioeconomic status}

1. Educational level of mother (ELM): No education (NE); Lower professional education (LPE); High school education (HSE); Higher education and University degree (HE and UD); Master degree and $\mathrm{PhD}$ (MD.; $\mathrm{PhD}$;), 
2. Educational level of father (ELF): No education (NE); Lower professional education (LPE); High school education (HSE); Higher education and University degree (HE and UD); Master degree and $\mathrm{PhD}(\mathrm{MD}$; $\mathrm{PhD}$;),

3. Employment of the mother (EM): unemployed, employed,

4. Employment of the father (EF): unemployed, employed.

Variables for testing phonological awareness

1. The ability to connect syllables (COSYL),

2. The Ability to connect phonemes (COPHO),

3. Rhyme (RHYME),

4. Phonemic segmentation (PHOSEG),

5. Phoneme ejectment (PHOEJC),

6. Phoneme displacement (PHODIS),

7. Spunerisms (SPUN),

8. Descriptive term of the phonological awareness (very low; low; below average; average; above average; high; very high).

\section{Method of conducting research and measuring in- strument}

The research was conducted in primary schools in the municipalities of Travnik and Novi Travnik in Bosnia and Herzegovina. The Phonological Awareness Test (Hatcher, 2000) was used to examine phonological awareness, which was translated and adapted into the Bosnian language. In the course of this test, the participants' ability was examined to connect syllables, connect phonemes, rhyme, phonemic segmentation, phoneme ejectment, phoneme displacement, and spunerisms. Each of these subtests contains the six items that were examined. The variable "The ability to connect syllables" was examined in such a way that the respondent, after hearing a spoken word disassembled on syllables by the examiner, connects the spoken words, or pronounces the word as a whole. The minimum score was 0 , and the maximum score was 6 points. The variable "The ability to connect phonemes" was examined so that the interpreter pronounced the word vox by vox, and the respondent was supposed to connect the spoken voxes, or pronounce the whole word. On this variable, the minimum score was 0 points, and the maximum score was 6 points.

The variable "Rhyme" was examined in such a way that the respondent was offered three words, two of which rhyme, and one did not. The respondent was asked to answer which of the three words he did not rhyme. For each correct answer the respondent received one point, and the point range ranged from 0 to 6 points. The variable "Phonemic segmentation" was examined so that the examiner pronounced the whole word, and the respondent was supposed to split the pronounced word into phonemes. The minimum score that the respondent could have achieved on this variable was 0 , and the maximum score was 6 points. The "Phoneme ejectment" variable was tested in a way that the whole word was pronounced for the respondent, and afterwards the interviewer was supposed to pronounce the same word, but without a certain vox. For each correct answer, the respondent received 1 point. The minimum score on this variable was 0 , and the maximum score was 6 points. The variable "Phoneme displacement" was examined so that the examiner pronounced the words, and the respondent should speak these words from the end to the beginning of the word. On this variable, the range of points obtained ranged from 0 to 6 . The variable "Spunerisms" was examined in the way that the examiner pronounced two words, one after the other, and the respondent should pronounce the first vox of the first word as the first vox of the second word, and the first vox of the second word should be pronounced as the first vox of the first word. The smallest number of points the respondent could achieve is 0 , and the maximum 6 points. Descriptive terms of development of phonological awareness are: very low, low, below average, average, above average, high and very high development of phonological awareness.

During the examination with the child, care must be taken to avoid giving non-phonological signs, especially in the part relating to the rhymes. Considering that it was possible to prepare a child for the expected response by changing the intonation, accent, volume, making a pause before the word or speech of the body in terms of changing contact with eyes, etc., all of the above was tried to be avoided in such a way that all the tasks were presented smoothly, without delay and in the same way. If a child asked for a task to be repeated, it was allowed to repeat it only once. Immediately after that, it was explained to the child that he/she needs to listen carefully, because the other words / voices will be spoken only once. The time limit was 10 seconds for each task. In order to prevent them from unnecessarily making mistakes and being wrong, the testing was interrupted if the child made a mistake in eight consecutive tasks.

The "Parent Questionnaire" was used to collect data related to socio-economic variables, which was constructed for the purposes of this research. 
The questionnaire was forwarded to the parents of the children involved in the research. Namely, both parents filled out a questionnaire asking questions about their level of education and employment. All respondents were individually examined by the said measuring instrument, with the prior consent of the school, as well as the parents.

\section{Statistical data processing}

Research data were processed in the statistical package SPSS 20.0 for Windows. The basic statistical parameters, measures of central tendency, dispersion measures, frequency and percentages were calculated, and a tabular presentation of results was performed. A multivariate regression analysis method and categorical regression analysis were used to check the hypothesized research findings. An alpha value of 5\% was used to assess statistical significance.

\section{RESULTS}

The research "The influence of the educational level and the employment of parents on the development of the phonological awareness of pupils of the lower primary school age" was conducted in the municipalities of Travnik and Novi Travnik in Bosnia and Herzegovina, encompassing a sample of 70 respondents. Of the total number of respondents, 37 male respondents had an average chronological age of $7.26 \pm .72$ years, and 33 respondents were females - average chronological age of $7.32 \pm .74$ years (Table 1). The results of the hi square test showed that there was no statistically significant difference between genders $(\chi 2=.22 ; p=.63)$.

Table 1. Measures of central tendency and dispersion measures

\begin{tabular}{lcccc}
\hline Gender & N & M & SD & SE \\
\hline Male & 37 & 7.26 & .72 & .11 \\
Female & 33 & 7.32 & .74 & .12 \\
\hline
\end{tabular}

Regarding the educational structure, it was found that the highest percentage of parents completed high school, while the smallest percentage of parents is without education. With high school education there is $58.57 \%$ of mothers, $31.43 \%$ of mothers are with lower professional education, while $5.71 \%$ of mothers have higher education and university degree. Com-

Table 2. Overview of parental education levels

\begin{tabular}{lcc}
\hline Variable & Mother \% & Father \% \\
\hline No education & 4.28 & 2.85 \\
Lower professional education & 31.43 & 21.43 \\
High school education & 58.57 & 70.00 \\
Higher education and University degree & 5.71 & 5.71 \\
\hline
\end{tabular}

The results in Table 3 show that, when it comes to employment, $57.1 \%$ of parents are employed, while $42.9 \%$ of parents are unemployed. Comparing the results of employment between mothers and fathers, it is evident that a higher percentage of fathers are employed $(78.6 \%)$ compared to mothers

(35.7\%). The results of the hi square test showed that the differences between parents relative to employment were statistically significant $(\chi 2=26.25$, $\mathrm{p}=.00$ ), or at the statistical significance level of .01 , the percentage of fathers employed in comparison with mothers.

Table 3. Overview of parents' employment

\begin{tabular}{lccc}
\hline Parents & Employment & & \\
\hline & & NO & YES \\
\hline Mother & $\mathrm{N}$ & 45 & 25 \\
& $\%$ & $64.3 \%$ & $35.7 \%$ \\
\hline Father & $\mathrm{N}$ & 15 & 55 \\
& $\%$ & $21.4 \%$ & $78.6 \%$ \\
\hline Total & $\mathrm{N}$ & 60 & 80 \\
& $\%$ & $42.9 \%$ & $57.1 \%$ \\
\hline
\end{tabular}

$\chi^{2}=26.25 ; \mathrm{p}=.00$ 
The results in Table 4 show that the highest percentage of respondents achieved 6 points on variables "The ability to connect syllables" (74.3\%), "Phonemic segmentation" (91.4\%) and "The ability to connect phonemes" (84.3\% ). On the variable "Rhyme", the highest percentage of respondents (32.9\%) achieved 2 points, $28.6 \%$ achieved 3 points, while
$18.6 \%$ achieved 4 points. On the "Phoneme ejectment" variable, the highest percentage of $21.4 \%$ of respondents achieved 4 points, while a proportionate percentage of respondents $(11.4 \%)$ achieved 0 and 1 point. On the variable "Spunerisms", the highest percentage of respondents achieved 0 and 1 point.

Table 4. Distribution of respondents in relation to variables of phonological awareness

\begin{tabular}{|c|c|c|c|c|c|c|c|c|}
\hline \multirow[t]{2}{*}{ Variables } & & \multicolumn{7}{|c|}{ Development of phonological awareness } \\
\hline & & $\mathbf{0}$ & 1 & 2 & 3 & 4 & 5 & 6 \\
\hline \multirow[t]{2}{*}{ COSYL } & $\mathrm{N}$ & - & - & - & - & 1 & 17 & 52 \\
\hline & $\%$ & - & - & - & - & 1.4 & 24.3 & 74.3 \\
\hline \multirow[t]{2}{*}{ COPHO } & $\mathrm{N}$ & 1 & 3 & - & - & 2 & 5 & 59 \\
\hline & $\%$ & 1.4 & 4.3 & - & - & 2.9 & 7.1 & 84.3 \\
\hline \multirow[t]{2}{*}{ RHYME } & $\mathrm{N}$ & 3 & 6 & 23 & 20 & 13 & 5 & - \\
\hline & $\%$ & 4.3 & 8.6 & 32.9 & 28.6 & 18.6 & 7.1 & - \\
\hline \multirow[t]{2}{*}{ PHOSEG } & $\mathrm{N}$ & 2 & - & 1 & - & 1 & 2 & 64 \\
\hline & $\%$ & 2.9 & - & 1.4 & - & 1.4 & 2.9 & 91.4 \\
\hline \multirow[t]{2}{*}{ PHOEJC } & $\mathrm{N}$ & 8 & 8 & 9 & 11 & 15 & 6 & 13 \\
\hline & $\%$ & 11.4 & 11.4 & 12.9 & 15.7 & 21.4 & 8.6 & 18.6 \\
\hline \multirow[t]{2}{*}{ PHODIS } & $\mathrm{N}$ & 7 & 6 & 7 & 6 & 8 & 14 & 22 \\
\hline & $\%$ & 10.0 & 8.6 & 10.0 & 8.6 & 11.4 & 20.0 & 31.4 \\
\hline \multirow[t]{2}{*}{ SPUN } & $\mathrm{N}$ & 26 & 30 & 7 & - & 2 & 4 & 1 \\
\hline & $\%$ & 37.1 & 42.9 & 10.0 & - & 2.9 & 5.7 & 1.4 \\
\hline
\end{tabular}

Legend: The ability to connect syllables (COSYL), The Ability to connect phonemes (COPHO), Rhyme (RHYME), Phonemic segmentation (PHOSEG),Phoneme ejectment (PHOEJC), Phoneme displacement (PHODIS), Spunerisms (SPUN)

The results in Table 5 show that the highest percentage of children had an average developed phonological awareness (34.29\%), while the smallest percentage of children, or one child, showed a very low and low developed phonological awareness. $4.29 \%$ of children showed below the average level of development of phonological awareness. The above-developed phonological awareness had $28.57 \%$ of children, $21.43 \%$ high and $8.57 \%$ very highly developed phonological awareness.

Table 5. Distribution of respondents in relation to the development of phonological awareness

\begin{tabular}{lc}
\hline Variable „Descriptive term of the phonological awareness“ & $\mathbf{\%}$ \\
\hline Very low & 1.43 \\
Low & 1.43 \\
Below average & 4.29 \\
Average & 34.29 \\
Above average & 28.57 \\
High & 21.43 \\
Very high & 8,571 \\
\hline
\end{tabular}

In order to determine the influence of the educational level of the parents on the development of the phonological awareness of pupils of the first and second grades of primary schools, the multivariate regression analysis method was applied. The obtained results in Table 6 show that the coefficient of multiple correlation is .39 , and the corrected coefficient of multiple correlation is .15 , indicating that $15 \%$ of the development of phonological awareness of the pupil can be explained under the influence of the educational level of the parent. The results of the F-coefficient showed that the educational level of the parents statistically significantly influenced the development of the phonological awareness of the pupils. 
Table 7 shows the results of a beta coefficient representing a standardized partial regression coefficient. From the table it can be noticed that the predictor "Educational level of the father" achieved a statisti- cally significant influence on the development of phonological awareness of pupils, that is, pupils whose fathers have a higher degree of professional development have a more developed phonological awareness.

Table 6. Results of regression analysis

\begin{tabular}{|c|c|c|c|c|c|c|}
\hline Dependent va & & SK & df & PSK & $\mathbf{F}$ & $p$ \\
\hline \multirow{2}{*}{$\begin{array}{l}\text { Phonological } \\
\text { awareness }\end{array}$} & Regression & 539.77 & 2 & 269.88 & \multirow{2}{*}{6.06} & \multirow{2}{*}{.00} \\
\hline & Residual & 2981.09 & 67 & 44.49 & & \\
\hline
\end{tabular}

$\mathrm{R}=.39 ; \mathrm{R}^{2}=.15$

Table 7. Results of beta coefficient

\begin{tabular}{llccc}
\hline Dependent variables & Predictors & Beta & $\boldsymbol{t}$ & $\boldsymbol{p}$ \\
\hline \multirow{2}{*}{ Phonological awareness } & Educational level of mother & .09 & .64 & .52 \\
\cline { 2 - 5 } & Educational level of father & .31 & 2.10 & $\mathbf{. 0 4}$ \\
\hline
\end{tabular}

A categorical regression analysis was applied in order to determine the influence of parents' employment on the development of phonological awareness of pupils of first and second grades in primary schools. The coefficient of multiple correlation is .36, and the corrected coefficient of multiple correlation is .13, indicating that $13 \%$ of the development of phonological awareness of the pupil can be explained under the influence of the parents' employment. The results of the F coefficient showed that the employment of parents statistically significantly influenced the development of the phonological awareness of the pupils (Table 8). Table 9 shows the results of the beta coefficient, and it can be noticed that both predictors "Employment of the mother" and "Employment of the father" have a statistically significant influence on the development of phonological awareness of pupils.

Also, in Table 9 it can be seen that the employment of the mother has a significant influence on the development of the phonological awareness of the pupils.

Table 8. Results of regression analysis

\begin{tabular}{|c|c|c|c|c|c|c|}
\hline Dependent va & & SK & df & PSK & $\mathbf{F}$ & $p$ \\
\hline \multirow{2}{*}{$\begin{array}{l}\text { Phonological } \\
\text { awareness }\end{array}$} & \multirow{2}{*}{$\begin{array}{l}\text { Regression } \\
\text { Residual }\end{array}$} & 9.43 & 2 & 4.71 & \multirow[b]{2}{*}{5.22} & \multirow[b]{2}{*}{.00} \\
\hline & & 60.56 & 67 & .90 & & \\
\hline
\end{tabular}

$\mathrm{R}=.36 ; \mathrm{R}^{2}=.13 ;$

Table 9. Results of beta coefficient

\begin{tabular}{llccc}
\hline Dependent variables & Predictors & Beta & F & $\boldsymbol{p}$ \\
\hline \multirow{2}{*}{ Phonological awareness } & Employment of the mother & .27 & 7.17 & $\mathbf{. 0 1}$ \\
\cline { 2 - 5 } & Employment of the father & .22 & 4.25 & $\mathbf{. 0 4}$ \\
\hline
\end{tabular}

\section{DISCUSSION}

In this research, whose main goal was to examine the influence of the educational level and employment of parents on the development of phonological awareness of pupils of the first and second grades of primary schools, the sample covered 70 respondents, of which 37 were male and 33 were female. The results of this research have shown that education of parents significantly influences the development of the pho- nological awareness of their children. The results obtained correspond with the results of other authors' research. Namely, parents play a fundamental role when it comes to speech - language development of a child. Also, parents need to provide an incentive voice environment by talking to the child about different topics and life situations. In doing this, they should take care to make the speech clear and adapted to the child's age. Telling a story is the simplest way of stimulating speech - language development. 
This initially involves listening to picture books, viewing images, detecting the essential ones. Noack (2004) states that more educated parents are more likely to provide better education, and help the child learn. Also, they place greater demands on the child, convey attitudes about the importance of schooling, and more involve the process of educating children. Eccles and Harold (1993) emphasize that scientists have evidence of the positive effects of parents' involvement in the education process. In this way, parents and schools continually encourage child development and learning. Research shows that parents with higher education are more involved in child education.

Previous research has shown that children who come from low socioeconomic backgrounds and whose mothers have low levels of education are at greater risk of academic failure (Washington, 2001, according to Martin, 2006). Regardless of the families' socioeconomic status, it is important to emphasize that active involvement of parents in their children's educational process is necessary for achieving better academic skills. Accordingly, Henderson and Berla (1994) state that children benefit greatly from the parental involvement in the education process. Children tend to achieve more regardless of the socioeconomic status, level of parental education, ethnic or racial affiliation if their parents are part of the process of their education. In this case, children achieve better results, regularly write homework, are less included in supplementary classes and less absent from school. Hoff (2003) points out that more educated parents talk more to children, they apply more complex and different language structures, resulting in more developed language and reading skills in the child. The results of Araújo and Costa (2015) survey show that the level of parenting is linked to the child's reading achievement. Feinstein (2000) states that parents' education is a very important indicator of his child's success. Fekonja-Peklaj and Marjanovič-Umek (2011) have shown in their research a significant link between the level of mother's education and the results of children aged 4 years and 1 month on a language test and a review of the story with pictures. The mothers of higher education provided children with a more stimulating environment: their speech is more directed to the child, they read the stories together with the child, go to the library and on children's plays. The results of the research carried out by Burushić, Babarović and Marković (2010) in Croatia on a sample of primary school pupils show that the impact of the education of the mother on the school achievement of children is, as a rule, somewhat greater than the father's. Goldin (2007, according to Pehlic \& Spahic-Jasarevic 2012) states that socioeconomic status is statistically significantly related to mother's involvement, indicating that mothers from a higher socio-economic layer are more involved in child's school life. We can conclude that poorly developed phonemic skills distinguish children from families of low socioeconomic status from their peers (Liberman, Rubin, Duques, \& Carlisle, 1985). Children who grow up with more educated parents of higher socioeconomic status have greater likelihood of meeting with developmentally appropriate books, reading, being encouraged by parents, and academic thinking (Noack, 2004).

In addition to parents 'education, the study also sought to determine the impact of parents' employment on the development of the phonological awareness of their children, whereby the results proved to be statistically significant. Employment of the mother affects the development of phonological awareness rather than the employment of a father. Hoffman (1998) found that maternal employment has a significant impact on children, or children of employed mothers achieve more academic results. Barling, Zacharatos and Hepburn (1999) developed and tested a model in which children who perceive their parents as uncertain about work, cognitively disturbed, negatively affecting their academic success. Matković (2010) states that richer parents who are more often and better educated personally help their children or give them help in the form of instructions, they can better lead children through the educational process. Williams Shanks et al.; (2010) emphasized that parents serve as models for children, transfer their aspirations and expectations, and develop the child's behavior needed to achieve the goals of education.

\section{CONCLUSION}

The results of this research have shown that the level of parental education affects the development of phonological awareness of pupils of first and second grades of primary school. Phonological awareness is more developed in pupils whose parents have a higher education level. The educational level of the father has more influence on the development of the phonological awareness of the pupils of the first and second grades of the primary schools, compared to the educational level of the mother. Also, it was found that the employment of parents affects the development of the phonological awareness of pupils of the first and second grades of primary schools. 
The children of the employed parents have a better developed phonological awareness. The obtained results indicate the need for speech and language therapists, during their professional work with children whose parents are unemployed and with lower education, to pay more attention to their development of phonological awareness. Therefore, professionals should devote more time to these children in reading letters and reading lessons, that is, they should pay more attention to the work and the provision of services that involve the adoption and development of prereading skills, because this difficulty can also be reflected in learning skills in other areas. Speech and language therapists should involve parents more in the child's school activities in order for them to participate directly with teachers and speech therapists through interactive cooperation in stimulating the child's speech-language development. Learning and developing all speech and language skills is very important for the educational and academic success of pupils, and by encouraging these areas by professionals and the family, we can provide a quality and adequate basis for the future development and improvement of children's abilities.

\section{REFERENCES}

Aikens, N. L., Barbarin, O. (2008). Socioeconomic differences in reading trajectories: The contribution of family, neighborhood, and school contexts. Journal of Educational Psychology, 100 (2), 235-251. http://dx.doi.org/10.1037/00220663.100.2.235.

Andrešić, D., Benc-Štuka, N., Gugo-Crevar, N., Ivanković, I., Mance, V., Mesec, I., Tambić, M. (2010). Kako dijete govori? Zagreb. Planet Zoe.

Anthony, J. L., Lonigan, C. J., (2004). The nature of phonological awarenes: Converging evidence from four studies of preschools and early grade school children. Journal of educational psychology, 96 (1), 43-55. http://dx.doi. org/10.1037/0022-0663.96.1.43.

Araújo, L., Costa, P. (2015). Home book reading and reading achievement in EU countries: the Progress in International Reading Literacy Study 2011 (PIRLS). An International Journal on Theory and Practice, 21(5-6), 422-438. https:// doi.org/10.1080/13803611.2015.1111803

Barling, J., Zacharatos, A., Hepburn, C. G. (1999). Parents' job insecurity affects children's academic performance through cognitive difficulties. Journal of Applied Psychology, 84(3), 437-44. http://dx.doi.org/10.1037/0021-9010.84.3.437.

Begić, L., Duranović, M., \& Karagić, S. (2016) Differences in language skills first grade students in relation to the length of attending kindergarten. Human Research in Rehabilitation, 6(2), 8-14. DOI: 10.21554/hrr.091602.

Burušić, J., Babarović, T., \& Marković, N. (2010). Koliko daleko padaju jabuke od stabla? Odnos obrazovnih postignuća djece i obrazovne razine njihovih roditelja. Društvena istraživanja, 19 (4-5), 709-730. https://hrcak.srce.hr/60111.
Čudina-Obradović, M., Obradović, J. (1995). Utjecaj bračnog emocionalnog sklada roditelja na školski uspjeh i ponašanje djece. Društvena istraživanja, 4(4-5), 627-639. https://hrcak.srce.hr/32370.

Eccles, J. S., \& Harold, R. D. (1993). Parent-school involvement during the early adolescent years. Teachers College Record, 94(3), 568-587.

Erić, I. (2014). Poticanje razvoja fonematskog sluha i fonološke svjesnosti kod djeteta s cerebralnom paralizom (Diplomski rad). Filozofski fakultet, Sveučilišta u Zagrebu. http:// darhiv.ffzg.unizg.hr/id/eprint/4476/1/(Eri\%C4\%87,\%20 Ivana.\%20Poticanje \%20razvoja\%20fonematskog\%20 sluha $\% 20 \mathrm{i} \% 20$ fonolo $\%$ C5\%A 1 ke $\% 20$ svjesnosti $\% 20$ kod $\% 20$ djeteta $\% 20 \mathrm{~s} \% 20$ cerebralnom $\% 20$ paralizom. 5.).pdf

Feinstein, L. (2000). The relative economic importance of academic, psychological and behavioural attributes developed in childhood. Centre for Economic Performance. London: London school of economics and Political Science.

Fekonja-Peklaj, U., \& Marjanovič-Umek, Lj. (2011). Family literacy environment and parental education relation to different measures of child's language. Suvremena psihologija, 14(1), 57-73. https://hrcak.srce.hr/83108.

Hatcher, P. J. (2000). Sound linkage: An integrated programme for overcoming reading difficulties, $2^{\text {nd }} \mathrm{ed}$. London, Whurr.

Henderson, A.T., Berla, N. (1994). A new generation of evidence: The family is critical to student achievement. Washington, DC. National Committee for Citizens in Education.

Hoff, E. (2003). The specificity of environmental influence: Socioeconomic status affects early vocabulary development via maternal speech. Child Development, 74 (5), 1368-1778.

Hoffman, L. W. (1998). The Effects of the Mother's Employment on the Family and the Child, http://parenthood.library. wisc.edu/Hoffman/Hoffman .html.

Kobola, A. (1977). Unapređivanje čitanja u osnovnoj školi. Zagreb. Školska Knjiga.

Leffel, K., \& Suskind, D. (2013). Parent-directed approaches to enrich the early language environments of children living in poverty. Seminars in speech and language, 34 (4), 267278. DOI: $10.1055 / \mathrm{s}-0033-1353443$.

Martin, N. R. (2006). The role of the home literacy environment in the development of early literacy skills and school readiness in kindergarten children from low socioeconomic and minority families (Graduate Theses and Dissertations). College of Education, University of South Florida. http:// scholarcommons.usf.edu/etd/2616.

Matković, T. (2010). Obrazovanje roditelja, materijalni status i rano napuštanje školovanja u Hrvatskoj: Trendovi u proteklom desetljeću. Društvena istraživanja, 19(4-5), 643667. https://hrcak.srce.hr/60108.

Noack, P. (2004). The family context of preadolescents' orientations toward education: Effects of maternal orientations and behavior. Journal of Educational Psychology, 96(4), 714-722. http://dx.doi.org/10.1037/0022-0663.96.4.714.

Pehlić, I.,\& Spahić-Jašarević, E. (2012). Akademska samoregulacija i učenička percepcija roditelja kao faktori školskog uspjeha. Zbornik radova Islamskog pedagoškog fakulteta $u$ Zenici br. 10/2012, 105-120. 
Smajlović, S., Begić, L., Karagić., S. (2017). Razlike u jezičkim sposobnostima učenika prvih razreda u odnosu na spol. VIII Međunarodna naučno-stručna konferencija Unapređenje kvalitete života djece i mladih, Tuzla, 2325- juni, 391-398.

Yopp, H. K. (1995). A Test for Assessing phonemic awareness in young children. The Reading Teacher, 49(1), 20-29.
Yopp, H. K., Yopp, R. H. (2000). Supporting phonemic awareness development in the classroom. The Reading Teacher, 54(2), 130-143.

Williams Shanks, T., Kim, Y., Loke, V., \& Destin, M. (2010). Assets and child well-being in economically developed countries. Children \& Youth Services Review, 32(11), 1488-1496. https://doi.org/10.7936/K76M36CV. 